\title{
Horizontal Cell Axon Terminals in Growing Goldfish
}

\author{
PAMELA A. RAYMOND* \\ Department of Anatomy and Cell Biology and The Neuroscience Program, The University of Michigan, \\ Ann Arbor, 48109-0616, U.S.A.
}

(Received 20 November 1989 and accepted in revised form 22 April 1990)

\begin{abstract}
In the retina of teleost fish, cone horizontal cell axons penetrate the inner nuclear layer, where they enlarge into fusiform terminal swellings. The present study shows that horizontal cell axon terminals enlarge disproportionately during postembryonic growth of the retina in juvenile and adult goldfish: the relative volume of axon terminals increases almost 20 -fold, while the volume of the entire retina increases only about fourfold during a 2-3-yr period. The enlarging axon terminals fill in the gaps created as the numerical density of nuclei in the inner nuclear layer falls. Horizontal cell axon terminals are thought to participate in cone-dominated visual pathways, although their precise role is unclear. The results of this study suggest that a comparison of horizontal cell function in small and large fish might help to resolve this issue.

Key words: retina; stereology; development; neurons; electron microscopy.
\end{abstract}

\section{Introduction}

Horizontal cells are second-order retinal neurons which are thought to participate in the generation of inhibitory surround regions in the receptive fields of bipolar cells and photoreceptors (Naka, 1977, 1982). Horizontal cells in fish are especially noteworthy for their unusually large size, which has facilitated their study with intracellular recording and dye-injection techniques (Kaneko, 1970. 1971; Naka, 1977; Sakai and Naka, 1983; Kaneko and Stuart, 1984). There are two principal types of horizontal cells in fish: those that receive input from cones and others that receive from rods (Stell, 1967, 1975: Kaneko, 1970; Naka, 1977). Cone horizontal cells have an axon which descends into the inner nuclear layer for a few hundred micrometers, whereupon it expands into a large, fusiform terminal over $100 \mu \mathrm{m}$ wide (Stell. 1975; Kouyama and Watanabe, 1986). The terminal swellings of cone horizontal cell axons are a prominent feature of many teleost retinas. They take up much of the space in the inner nuclear layer (Stell, 1975). especially in those fish typically uscd for clectrophysiological studies (large goldfish, carp and catfish).

Despite their structural prominence, the function of horizontal cell axon terminals is not well understood. It is known that their graded electrophysiological responses to illumination are similar to those of the parent cell bodies (Kaneko, 1970; Weiler and Zettler. 1979: Yagi and Kaneko, 1988), and that there are three distinct spectral types of cone horizontal cells (Stell and Lightfoot, 1975; Marc et al., 1978; Drujan and I aufer. 1982). Horizontal cells of the same spectral type make extensive gap junctional contacts with each

\footnotetext{
* For correspondence at: Department of Anatomy and Cell Biology, The University of Michigan Medical School, 4610 Medical Science II. Ann Arbor. MI 48109-0616, It.S.A.
}

other and their axon terminals are coupled likewise to others of the same type (Kaneko and Stuart, 1974; Marc et al., 1978; Kouyama and Watanabe, 1986). The axon terminals receive no direct input from photoreceptors (Stell, 1975).

In the electron microscope the axon terminals are easily recognized by their cylindrical shape and their distinctive cytoplasm, packed with longitudinal arrays of microtubules (Wolburg. 1976; Marc and Liu, 1984; Sakai and Naka, 1985, 1986; Marshak and Dowling. 1987). Synapses made by or onto horizontal cell axon terminals have been recently described in catfish (Sakai and Naka, 1985, 1986) and goldfish (Marc and Liu, 1984; Marshak and Dowling, 1987). The identified neurons that receive synapses from axon terminals include amacrine cells (Sakai and Naka, 1985, 1986; Marshak and Dowling, 1987), glycinergic interplexiform cells (Marc and Liu, 1984), dopaminergicinterplexiform cells (Zucker and Yazulla, 1984; Marshak and Dowling, 1987) and bipolar cells (Marshak and Dowling, 1987). All reports commented that synapses were rare; they were found on less than $1 \%$ of the profiles of axon terminals examined (Sakai and Naka, 1986; Marshak and Dowling, 1987).

In the course of investigations on postembryonic retinal growth in goldfish, I noted that in small (young) fish, horizontal cell axon terminals were small and inconspicuous, and the inner nuclear layer was primarily composed of perikarya of the neurons and Müller glia that reside there. In larger (older) fish, the axon terminals were much more prominent and had increased markedly in size. There was a concomitant decrease in the density of nuclei in the inner nuclear layer, and the empty spaces thus created were filled by the axon terminals. The data reported here document these observations. These results confirm and extend a recent report by Peng and Lam (1989, pers. commun.) 


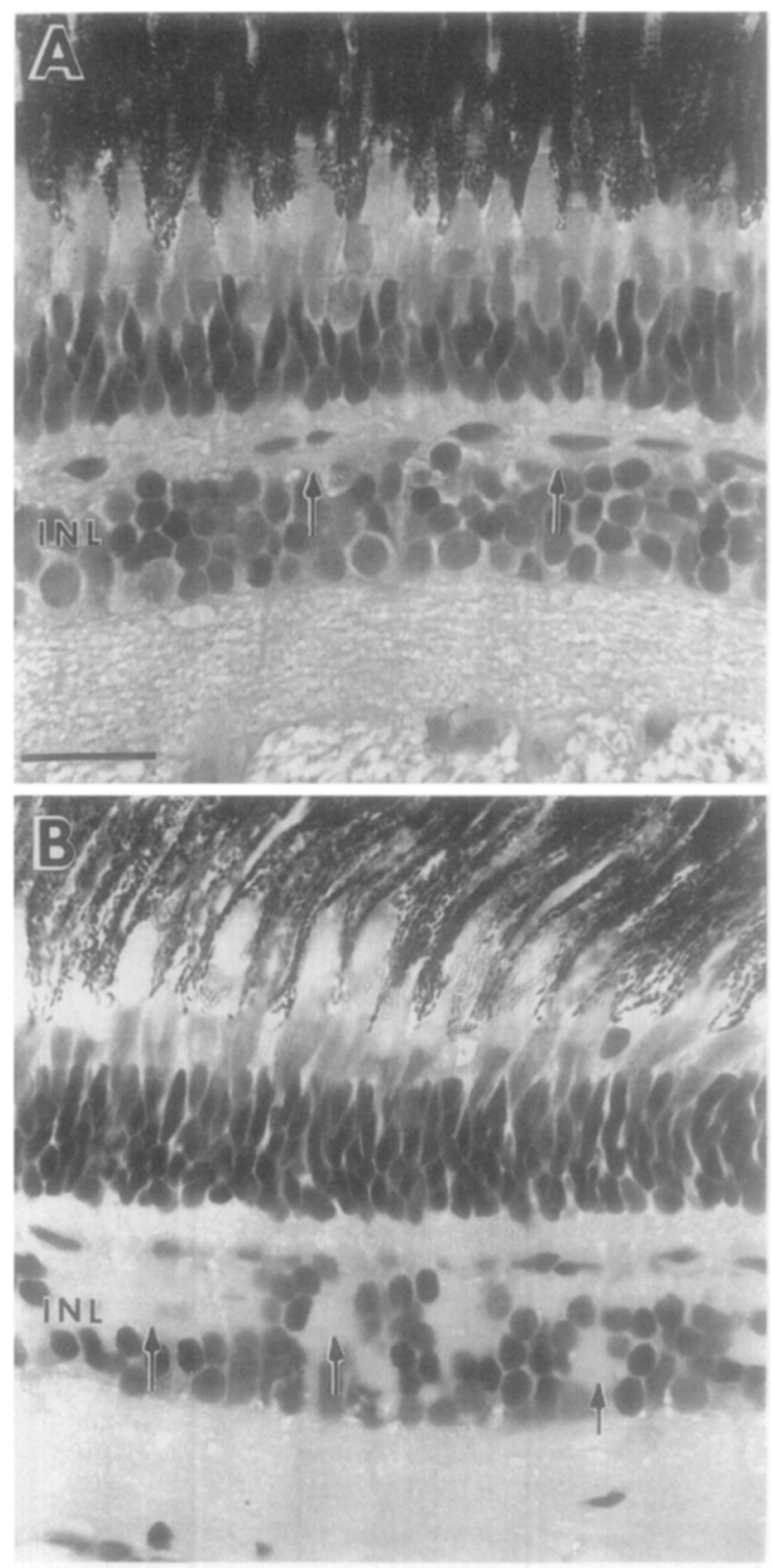

FIG. 1. Light-microscopic comparison of retinal sections from a small (A) and a large (B) goldfish. Inner nuclear layer, INL. Arrows indicate horizontal cell axon terminals. See text for details. Bar $=20 \mu \mathrm{m}$.

in which a monoclonal antibody selective for horizontal cell axon terminals was used to identify these processes in growing goldfish.

\section{Materials and Methods}

Light Microscopic Procedures and Morphometric Analysis

Four goldfish, 3.4-14.5 cm body length (tip-of-nose to base-of-tail), were used. Goldfish of this size range from 1 to 3 yr old (Johns and Easter, 1977). Fish were anesthetized in $0.2 \%$ methane tricaine sulfonate (Sigma, St Louis, MO) and killed by decapitation. The eyes were removed, the corneas were opened, the lenses were taken out, and the lens diameters were measured with a caliper. Eye cups were fixed in $3.2 \%$ glutaraldehyde, $3 \%$ paraformaldehyde, $0.1 \%$ picric acid, $1.5 \%$ dimethylsulfoxide (DMSO), $1 \mathrm{mM} \mathrm{CaCl} 2$ in $0 \cdot 1 \mathrm{~m}$ sodium cacodylate buffer, $\mathrm{pH} 7 \cdot 4$, for $3 \mathrm{hr}$ at room temperature, and then overnight at $4^{\circ} \mathrm{C}$. After rinsing in buffer, eye cups were bisected along the vertical or horizontal meridian, dehydrated in graded ethanols and embedded in glycol methacrylate (JB-4 resin, Polysciences, Warrington, PA). Sections were cut at $3 \mu \mathrm{m}$ and stained with hematoxylin and eosin.

One section from each of the four retinas (one from each fish), was selected from near the center of the eye. Eight sampling regions were identified from each retina. Samples consisted of segments of inner nuclear layer about $80 \mu \mathrm{m}$ long spaced equally across the retina from one margin to the other, except that the most peripheral $10 \%$ of the retina on each side was excluded. [The retina nearest the margin was eliminated from the analysis because it consists of the most recently added, newest retinal cells and is in many respects less mature than, and hence different from. more central regions (Johns, 1977, 1982). See also Figs 2(C) and (D).] Within each sample, camera lucida drawings using a $100 \times$ oil immersion objective were made of all nuclei and all profiles of horizontal cell axon terminals. Final magnification on the drawings was $860 \times$. Nuclei were strained blue to violet by the hematoxylin and axon terminals were stained bright pink by the eosin. A total of 1350 nuclear profiles and 560 profiles of axon terminals were drawn .

I'he areas occupied by nuclei and axon terminals in each sample were determined by tracing the borders of the inner nuclear layer (INL) in the sample region, along with all profiles contained within it, onto the digitizing tablet of a Zeiss MOP-3 morphometric computer.

From stereological principles it has been shown that the relative area occupied by a given class of profile on a set of random sections is equivalent to the relative volume (or volume density) of that component in the tissue as a whole (reviewed in Weibel and Bolender, 1973). Therefore, from the planimetric measurements obtained with the Zeiss MOP-3, we determined the volume densities of nuclei and axon terminals in the INL.

The numerical density (No. $\mathrm{mm}^{-3}$ ) of nuclei in the INL was determined from the number of cells, corrected for split nuclei with a modified Abercrombie formula (Konigsmark, 1970). Nuclei were counted within a slab of INL of known area and depth equal to the section thickness $(3 \mu \mathrm{m})$. The mathematical equations for determining numerical density are valid only for spherical particles, and since axon terminals are cylindrical, their numerical density could not be determined.

The change in total retinal volume with growth was estimated from the change in lens diameter. by using the following proportionalities. Lens diameter in 
goldfish is linearly related to the meridional retinal length (the maximum distance along the retina from one ciliary margin to the other) by the following relation: retinal length $=3.8 \times$ lens diameter (Easter, Johns and Baumann, 1977).

The retina itself approximates a portion of a sphere, $185^{\circ}$ in angular subtense (Easter, Johns and Baumann, 1977). Therefore, the planimetric area of the retina can be calculated from spherical geometry (Johns and Easter, 1977), and is equivalent to $0.64 \times$ (retinal length) $^{2}$. The retinal volume is equal to the planimetric area times the retinal thickness. Although the thickness of the retina varies depending on retinal location, it is approximately the same in small and large fish at equivalent locations (Raymond, unpubl. res.). Therefore the change in total retinal volume with growth is proportional to the change in planimetric area.

\section{Electron Microscopic Procedures}

Fish were anesthetized and eyes were fixed as described above, except that DMSO was omitted and $5 \%$ sucrose was added to the fixative. After rinsing in buffer, eyes were cut along various meridians into wedges with a maximum width of $1.5 \mathrm{~mm}$. The number of pieces varied depending on the size of the eye. For larger eyes, the wedges were further divided into central and peripheral parts. (Observations reported here are confined to central regions of the retina.) Tissues were postfixed in $2 \%$ osmium tetroxide in $0 \cdot 1 \mathrm{M}$ cacodylate buffer, $\mathrm{pH} 7 \cdot 4$, for $2 \mathrm{hr}$ at room temperature. After rinsing in $0.1 \mathrm{M}$ sodium acetate buffer, $\mathrm{pH} 5 \cdot 1$, tissues were stained en bloc in $2 \%$ uranyl acetate overnight at $4^{\circ} \mathrm{C}$, dehydrated in graded ethanols and embedded in either a mixture of Epon 812/Araldite 502 or Spurr (Polysciences). Sections were viewed and photographed on a Philips 400 electron microscope.

\section{Results}

Histology of the Inner Nuclear Layer in Small and Large Fish

Figure 1 compares the central retinas of a small goldfish $(3.4 \mathrm{~cm}$ standard body length) and a larger one $(7.8 \mathrm{~cm}$ long). At the top of the inner nuclear layer (INL) the darkly-stained, flattened, elongated nuclei of horizontal cells are easily seen. In the small fish the remainder of the INL is a heterogenous collection of darkly-stained nuclei [Fig. 1(A)]. In the larger fish, however, there are what appear to be gaps in the carpet of nuclei, especially in the upper parts of the layer [Fig. 1(B)]. These 'gaps' are not empty but are filled with horizontal cell axon terminals, stained a bright pink. With the aid of the color contrast provided by the stains when looking through the microscope, one finds that there are also pink-stained axon terminals in the smaller retina [arrows on Fig. 1(A)], though they are less frequent and not as large. They are not easily visualized on the black-and-white photograph.

Four camera lucida drawings representative of the samples that were used for morphometric measurements are illustrated in Fig. 2. The first three [(A), (B) and (C)] are from the central retina of three fish $(3.4$ $\mathrm{cm}, 7.6 \mathrm{~cm}$ and $14.5 \mathrm{~cm}$ standard body length, respectively). In these drawings the relative sizes and distributions of nuclei and axon terminals in the INL can be appreciated. Note the marked increase in size of the axon terminals and increase in the relative fraction of space that they occupy as the fish grows larger. Further evidence that these changes in the organization and composition of the INL, especially the enlargement of axon terminals, actually reflects growth and maturation of the retina is provided by Fig. 2(D). This is a drawing of the INL at the extreme peripheral edge of the retina of the largest fish, whose central retina is represented in Fig. 2(C). Note that the axon terminals are smaller in Fig. 2(D) than in Fig. $2(\mathrm{C})$, and in size and density they resemble those in the central retina of smaller fish [Figs 2(B) and (C)]. The retina in goldfish continues to grow by addition of new neurons at the margin (Johns, 1977; Meyer, 1978), and the small size of the axon terminals in peripheral retina is consistent with the notion that they are younger versions of those in central retina. These observations suggest that axon terminals enlarge as the retina grows.

\section{Magnitude of Axon Terminal Growth}

The results of the morphometric analysis of axon terminals and cell nuclei in the INL are shown in Figs $3-5$. The areas of all axon terminals and all nuclear profiles in a given sample were summed separately, and the ratio (axon terminals/nuclei) was calculated for each of the eight samples from each retina. On Fig. 3 the mean ratios for each retina are plotted as a function of the lens diameter, which is a convenient and accurate index of ocular size (Johns, 1982). Although what we measured were ratios of the summed areas of axon terminals and nuclear profiles, by the principles of stereology we can equate area ratios with volume ratios (Weibel and Bolender, 1973). which is the more relevant parameter. Thus, Fig. 3 shows the increase in the volume of axon terminals compared to the volume of cell nuclei as a function of ocular growth. This ratio increases about 17 -fold over the range of sizes studied. In the largest fish, axon terminals occupy more space than do INL nuclei (the ratio exceeds $1 \cdot 0$ ).

There are two factors that contribute to the change in relative contributions of axon terminals and nuclei with growth. First, the volume density (the fraction of total INL space occupied by nuclei) in large fish is about half that of small fish [Fig. 4(A)], and the decrease is accounted for by a decrease in numerical 


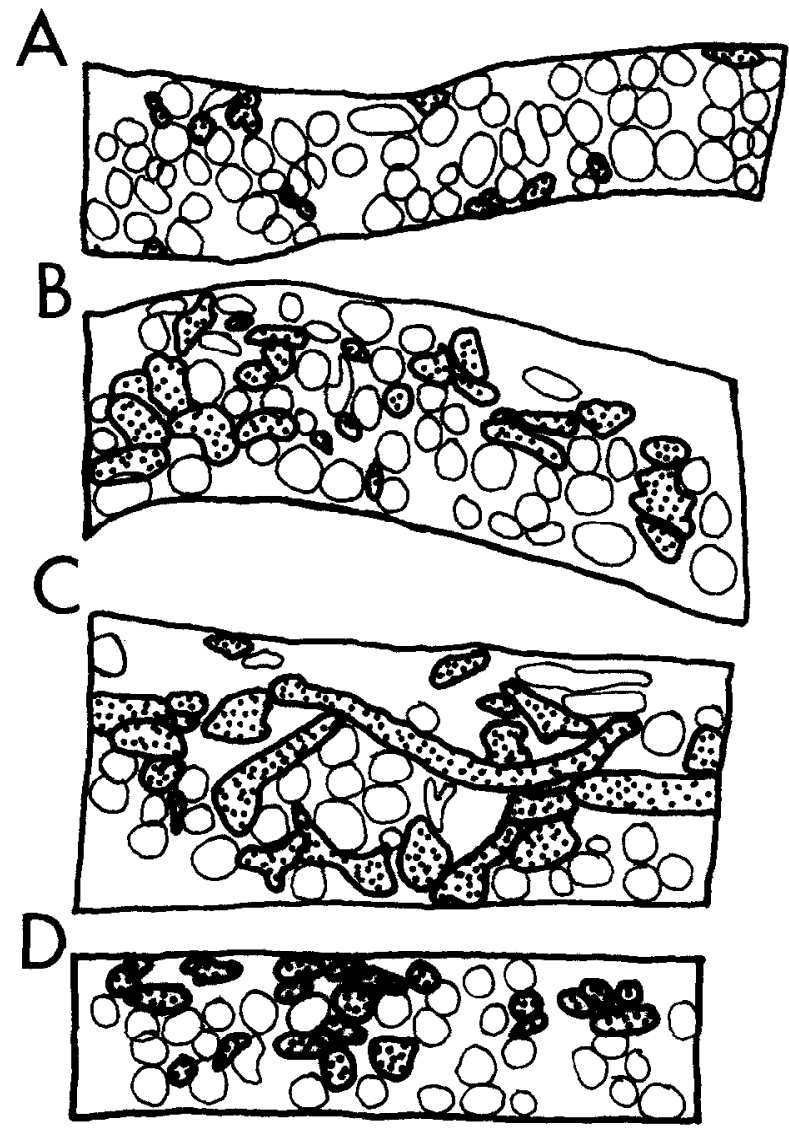

FIG. 2. Camera lucida drawings of representative samples used in the morphometric analysis. The rectangular box delineates a segment of inner nuclear layer, $80 \mu \mathrm{m}$ long. The open profiles are cell nuclei and the stippled profiles are horizontal cell axon terminals. A, Small fish, central retina; $B$, medium fish, central retina; $C$, large fish, central retina; D. large fish peripheral retina.

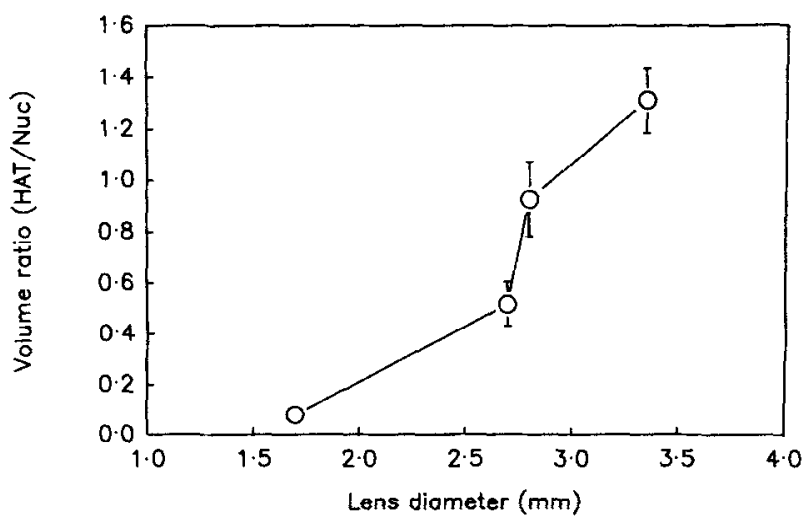

FIG. 3. The ratio of the volume density of horizontal cell axon terminals (HAT) divided by the volume density of nuclei in the inner nuclear layer (Nuc) is plotted as a function of lens diameter. Each point is the mean \pm 1 s.E. of eight samples from one retina.

density of nuclei [Fig. 4(B)]. Nuclear diameters actually increase, hut only sightly, from an average of $3.8 \mu \mathrm{m}$ to $4.2 \mu \mathrm{m}$ (about a $10 \%$ increase) as the retina grows. We can therefore conclude that the spaces between nuclei must enlarge, and it is into these spaces that the
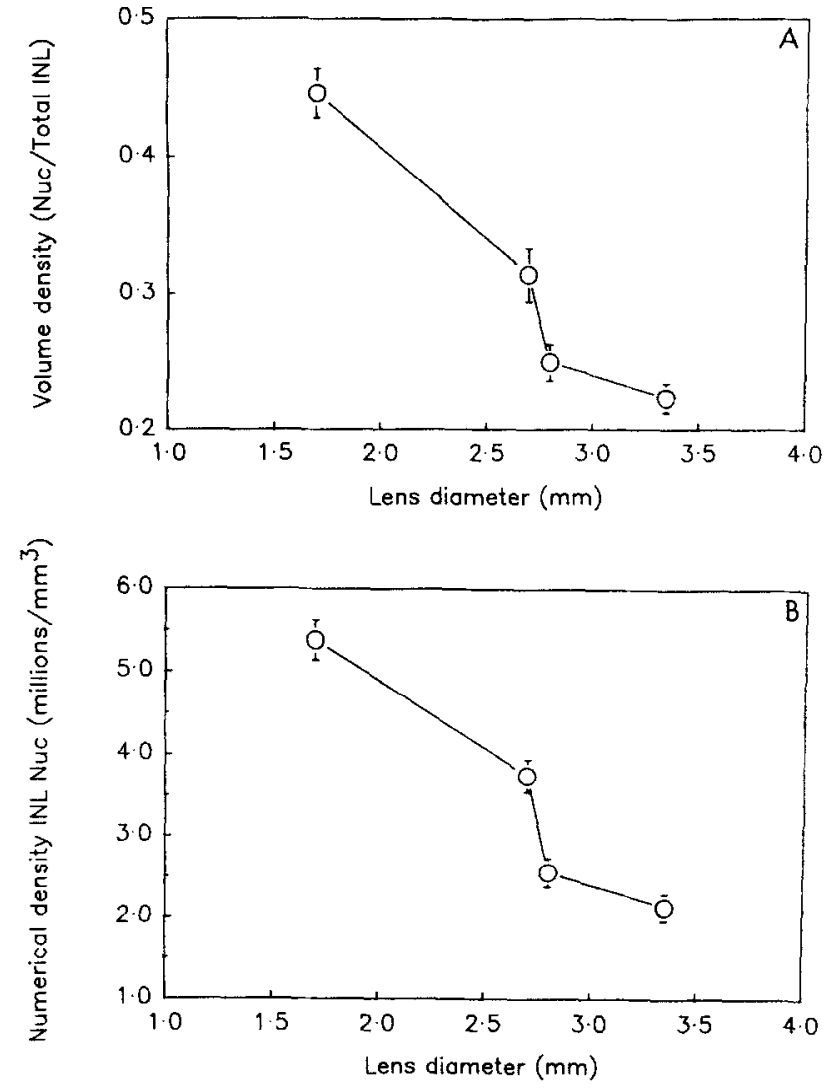

Fig. 4. A. The fraction of the total volume of the inner nuclear layer (INL) occupied by cell nuclei (Nuc) is plotted as a function of lens diameter. B. The numerical density of nuclei in the inner nuclear layer as a function of lens diameter. Each point is the mean \pm 1 S.E. of eight samples from one retina.

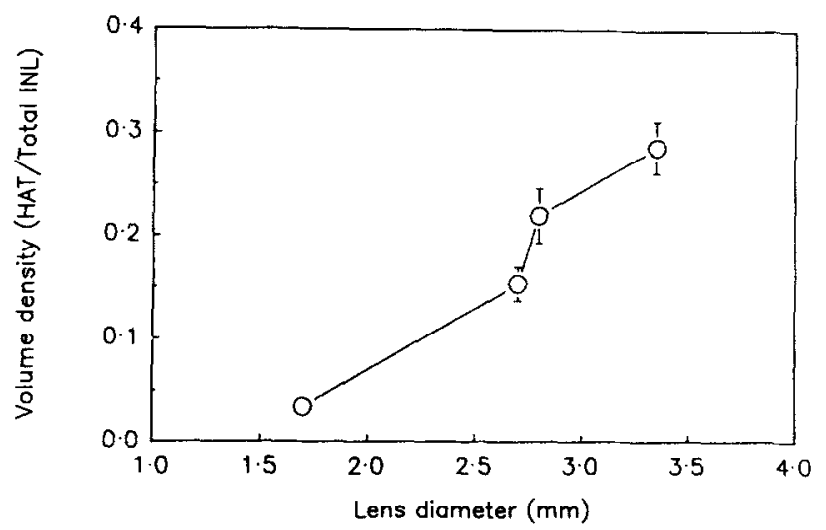

FIG. 5. The fraction of the total volume of the inner nuclear layer (INL) occupied by horizontal cell axon terminals (HAT) plotted as a function of lens diameter. Each point is the mean \pm 1 s.E. of eight samples from one retina.

axon terminals grow. Growth of axon terminals is the second factor, and the more important one, that contributes to the increased ratio in Fig. 3. The volume density (fraction of the total volume of the INL occupied by horizontal cell axon terminals) increases over eightfold as the eye grows (Fig. 5).

The total retinal area increased from $28 \mathrm{~mm}^{2}$ in the smallest fish to $104 \mathrm{~mm}^{2}$ in the largest, which 

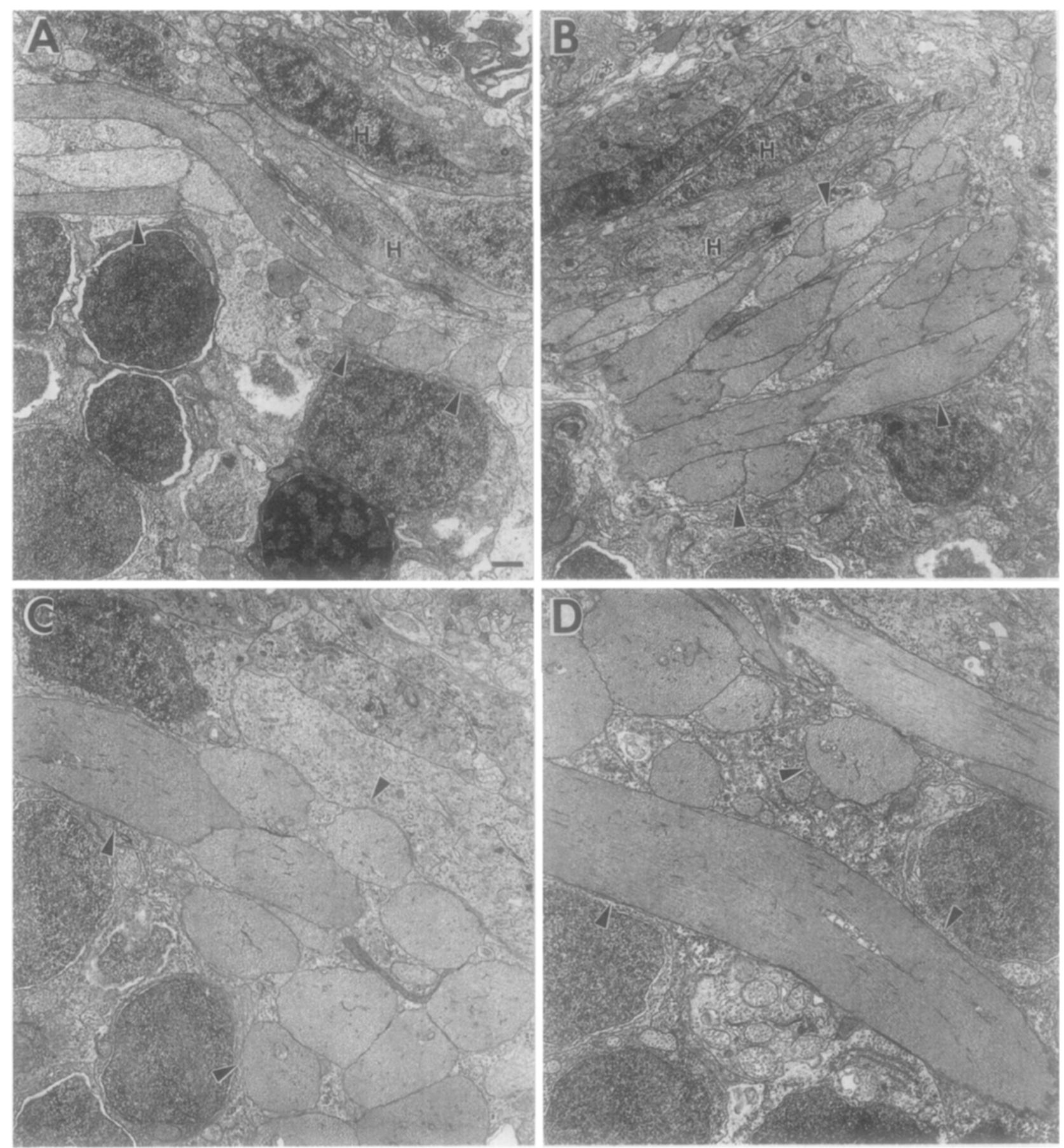

FIG. 6. Electron micrographs of the inner nuclear layer in goldfish of different sizes: A, B, Small fish; C, D, medium fish. Horizontal cell axon terminals (arrowheads) are easily recognized by their cylindrical shape, electron lucent cytoplasm. and abundant microtubules. A, B. In small fish, the axon terminals are small and most are close to the cell bodies of the horizontal cells $(\mathrm{H})$. Rod and cone synaptic terminals in the outer plexiform layer are seen at the top $\left.{ }^{*}\right)$. C, D, In larger fish, the horizontal cell axon terminals are wider (over twice as wide in the $8-\mathrm{cm}$ fish compared to the 3-and 4-cm fish). In addition, the terminals penetrate farther into the inner nuclear layer. Bar $1 \mu \mathrm{m}$.

represents a 3.9-fold increase. Because the retinal widths were comparable, we can conclude that retinal volume also increased by about fourfold as the eye grew.

\section{Ultrastructural Observations}

Examples of horizontal cell axon terminals in small and large goldfish are shown in Figs 6 and 7. The low magnification, survey micrographs in Fig. 6 illustrate the relative size and position of axon terminals in the INL. In small fish [3-4 cm body length, Figs $6(\mathrm{~A})$ and (B)] the terminals tend to cluster, especially along the outer border of the INL, adjacent to the perikarya of horizontal cells. The caliber of the terminals is relatively small $(1.44 \mu \mathrm{m} \pm 0.32 \mu \mathrm{m}$ in diameter. mean \pm s.D.. $n=34$ ). The profiles visualized and traced in the light microscopic sections were probably 

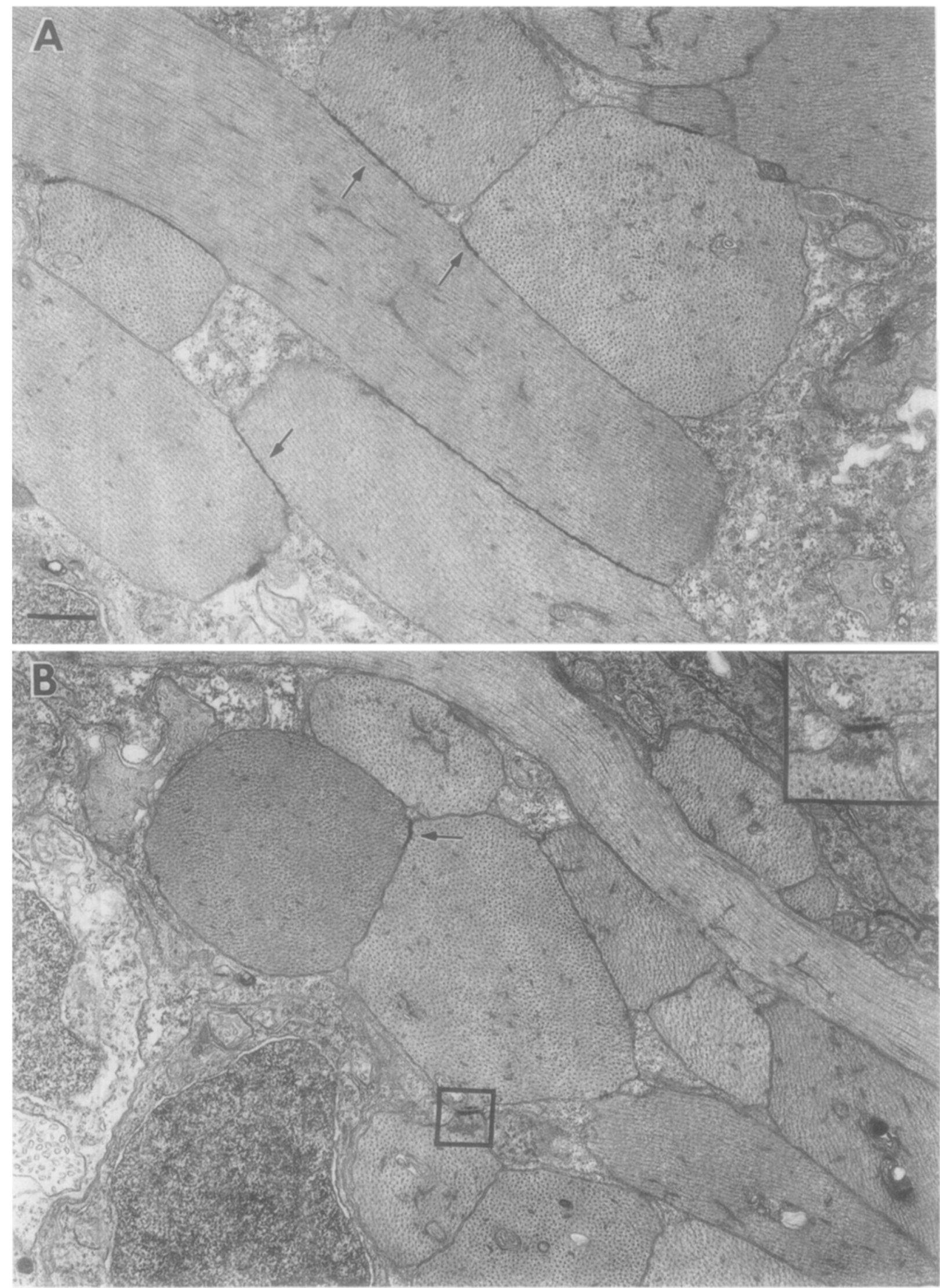

FiG. 7. Electron micrographs of horizontal cell axon terminals in the inner nuclear layer. Note the abundant, regularlyspaced, microtubules running along the length of the cylindrical axonal processes. The axon terminals are connected by extensive gap junctions (arrows). The regular punctate structure of the gap junction represents symmetrical paramembrane densities at areas of intercellular apposition and are characteristic of gap junctions in teleost horizontal cells (Marc et al.. 1978). The inset to panel B shows an axon terminal containing a collection of electron-lucent vesicles near a gap junction between adjacent axon terminals (arrow). Bar $1 \mu \mathrm{m}$. 
composed of such bundles. Within each bundle, the terminals run approximately tangentially (i.e. parallel to the retinal surface) and roughly orthogonally to one another [Fig. 7(A)], forming a meshwork vitread to the layer of horizontal cell perikarya [Fig. 6(B)].

In the retina from a larger fish ( $8 \mathrm{~cm}$ body length) illustrated in Figs $6(C)$ and (D), the axon terminals are larger $(2 \cdot 88 \pm 0.65 \mu \mathrm{m}, n=31)$ and more often penetrate far into the INL. Both of these observations are consistent with what was seen in the light microscope. Bundles of terminals are still common in larger fish, especially in the outer part of the INL [Fig. $6(C)$ ]. Very rarely. we saw ccllections of vesicles [Fig. 7(B)] similar to those described by Marshak and Dowling (1987). Horizontal cell axon terminals were seen participating in chemical synapses in both small and large fish. The amount of material examined was insufficient to make quantitative comparisons of numbers or density of synapses in different sized fish.

\section{Discussion}

This study has shown that axon terminals of cone horizontal cells in goldfish enlarge disproportionately and come to dominate the inner nuclear layer as the eye grows in juvenile and adult fish. The swelling of axon terminals occurs in part at the expense of perikarya in the inner nuclear layer: the volume density of axon terminals increases almost 20-fold as the retina grows to four times its original volume. while at the same time the volume density of INL nuclei shrinks to half its original value. This loss in nuclear volume density is due to a decrease in numerical density; the nuclei themselves actually increase slightly in size. The horizontal cell axon terminals, in contrast, increase greatly in size, filling in the spaces between nuclei, and as a result axon terminals become a prominent feature of the INL in large goldfish. In fish larger than about $10 \mathrm{~cm}$ standard body length ( $3 \mathrm{~mm}$ lens diameter), axon terminals occupy more space than all the neuronal and glial nuclei in the INL combined.

Recently D. M. K. Lam and colleagues have generated a monoclonal antibody that selectively labels horizontal cell axon terminals in goldfish. By using this antibody to identify axon terminals immunocytochemically on sections of retina from different sized fish, they concluded, in agreement with the results reported here, that axon terminals expand greatly during postembryonic growth (Peng and Lam, 1989; pers. commun.). In 2-week-old larval goldfish, the antibody fails to detect any axon terminals (D. M. K. Lam, Y. W. Peng and P. A. Raymond, unpubl. res.), suggesting that growth and maturation of these processes is entirely a postembryonic developmental event.

The magnitude of the increase in size of horizontal cell axon terminals far surpasses the growth of other neuronal components in the goldfish retina. For example, Hitchcock and Easter (1986) showed that the dendritic field of a particular class of large, unistratified ganglion cell (their subtype 1-2) increased in area by about threefold over approximately the same range of sizes of fish as those used in the present study. Even smaller changes were seen by Kock and Stell (1985) in the dendritic field of a certain type of rod bipolar cell (called $b_{1}$ ), which increased in area by only about $30 \%$ during this growth interval. Thus, the axon terminals of cone horizontal cells are unique in the magnitude of their growth response.

The only other growth-related change of comparable magnitude in this retina is the addition of rod photoreceptors: there are about 1.5 million rods in a 3-cm fish and about 15 million in a $15-\mathrm{cm}$ fish. a tenfold increase (Johns and Easter, 1977). These new rods are generated continuously from scattered rod precursor cells located in the layer of photoreceptor nuclei, the outer nuclear layer (Sandy and Blaxter, 1980: Johns and Fernald, 1981: Johns, 1982). Rod addition continues in the growing adult retina, and only rods are added to central retina. As a result, the ratio of rods to cones (or rods to ganglion cells or any other neuron) increases continuously with growth (Johns, 1982; Powers et al., 1988).

Teleost horizontal cells are among the best studied neurons in the vertebrate retina. Their large size and the extensive electrical coupling among horizontal cells has made them an easy target for the electrophysiologist's microelectrode. Since 1953, when Svaetichin first penetrated a horizontal cell in an isolated fish retina and recorded a graded hyperpolarizing response to light (called the S-potential). these cells have received a great deal of attention, and a lot is known about their anatomy, biochemistry and physiology (see reviews by Kaneko, 1970; Yazulla, 1985; Piccolino, 1986). Nevertheless, their function is not completely understood.

Horizontal cells are thought to be primarily involved in mediating the lateral inhibitory surround mechanisms of bipolar (and photoreceptor) cells (Naka, 1977, 1982; Marc and Liu, 1984). Horizontal cells that receive input from cones have long axons that penetrate the INL and terminate in a fusiform swelling (Stell, 1967. 1975). Unlike horizontal cells in other vertebrates, in fish the axon terminals do not receive direct input from photoreceptors (Stell, 1975), but nevertheless the spatial and spectral receptive field properties of axon terminals are similar to those of the parent cell body (Naka, 1977, 1982 ; Teranishi, 1983; Kaneko and Stuart, 1984, Negishi, Teranishi and Kato, 1985; Kouyama and Watanabe, 1986). It is thought that light-evoked responses in horizontal cell bodies are conducted along the axon to the terminal and thence distributed via gap junctions to the network of axons and axon terminals (Kouyama and Watanabe, 1986; Yagi and Kaneko, 1988). The axon terminals also participate in chemical synapses; they are presynaptic to amacrine, bipolar and inter- 
plexiform cells, and receive synaptic input from dopaminergic interplexiform cells (Dowling and Ehinger, 1978; Zucker and Yazulla, 1984; Marshak and Dowling, 1987). However, the relative roles of chemical and electrical synaptic transmission in horizontal cell function are not clear, nor is it known why the axon terminal expands, and what role it plays as distinct from the parent cell body.

Much of the recent electrophysiological and pharmacological work on horizontal cell function has focused on understanding the role of dopamine and the state of light and dark adaptation in modulating horizontal cell activity. Application of dopamine alters the spatial properties of the cone horizontal cell response to light, increasing the amplitude of the Spotential but decreasing its lateral spread by uncoupling gap junctions (Teranishi, Negishi and Kato, 1983; Hida, Negishi and Naka, 1984). This effect is thought to be mediated endogenously by dopaminergic interplexiform cells, which are presynaptic to cone horizontal cells, and thereby provide a feedback circuit from the inner layers (Dowling and Ehinger, 1978). Although the effects of dopamine are generally thought to mimic light adaptation, there is some controversy about this issue (Mangel and Dowling, 1985: Tornqvist, Yang and Dowling, 1988: Yang, Tornqvist and Dowling, 1988a, b). Despite the fact that both cell body and axon terminal receive chemical synaptic input from dopaminergic interplexiform cells, the response properties of axon terminals are not modified by application of dopamine (Hida, Negishi and Naka, 1984). The cell bodies and axon terminals of teleost horizontal cells also differ in their response to agents that evoke release of $\left[{ }^{3} \mathrm{H}\right] \mathrm{GABA}$. Both cell bodies and axon terminals of the predominate type of cone horlzontal cell (H1) take up exogenous $\left[{ }^{3} \mathrm{H}\right] \mathrm{GABA}$, and agents that depolarize the cell, including the natural stimulus, darkness, evoke release of $\left[{ }^{3} \mathrm{H}\right] \mathrm{GABA}$ from cell bodies but not axon terminals (Yazulla, 1985). Dopamine inhibits the evoked release of $\left[{ }^{3} \mathrm{H}\right] \mathrm{GABA}$ from cell bodies (Yazulla, 1985). Thus, despite the similarities in their electrophysiological responses to photic stimulation, the cell body and axon terminal of horizontal cells must have unique, but as yet unspecified, roles in retinal function.

The results reported here demonstrate that the expansion of axon terminals is a very late developmental event, and is part of a slow maturational process that accompanies postembryonic growth of the retina by stretching (Johns and Easter, 1977; Hitchcock and Easter, 1986). Growth by stretching is associated with a decrease in numerical density of cells in the INL and a concomitant swelling of cone horizontal cell axon terminals. The expansion of axon terminals cannot be an entirely passive event, since it must involve the concurrent selective formation of gap junctional connections among terminals of the same spectral type and the establishment of chemical synaptic connections with certain other interneurons in the INL. Since no new neurons are added to the INL during this period of growth, these events suggest that remodeling of synaptic connectivity is an ongoing process in the adult teleost retina (Johns and Easter, 1977; Fisher and Easter, 1979; Hitchcock and Easter, 1986).

The weight of anatomical and electrophysiological evidence suggests that horizontal cell axon terminals are primarily involved in cone pathways. Therefore, future biochemical, physiological and pharmacological efforts to understand the regulation of information flow through cone pathways and the role played by horizontal cells might benefit from a comparison of small and large retinas.

\section{Acknowledgments}

Thanks to Ms Linda Barthel and Ms Laurie Sultz for technical assistance, and to Dr Stephen S. Easter. Jr. for the use of his MOP-3 morphometric computer and for his critical reading of the manuscript, which Ms Sharon Moskwiak typed. Supported by NIH FYO4318 and a Sloan Foundation Fellowship to PAR. Pamela A. Raymond has published previously as Pamela R. Johns.

\section{References}

Dowling, J. E. and Ehinger, B. (1978). The interplexiform cell system I. Synapses of the dopaminergic neurons of the goldfish retina. Proc. R. Soc. Lond. (Biol.) 201, 7-26.

Drujan, B. D. and Laufer, M. (Eds) (1982). The S-potential. Alan R. Liss: New York.

Easter, S. S., Johns, P. R. and Baumann, L. R. (1977). Growth of the adult goldfish eye - I: Optics. Vision Res. $17,469-77$.

Fisher, L. J. and Easter, S. S. (1979). Retinal synaptic arrays: continuing development in the adult goldfish. J. Comp. Neurol. 185, 373-9.

Hida, E., Negishi, K. and Naku, K.-I. (1984). Effects of dopamine on photic L-type S-potentials in the catfish retina. J. Neurosci. Res. 11. 373-82.

Hitchcock, P. F. and Easter, S. S. (1986). Retinal ganglion cells in goldfish: A qualitative classification into four morphological types, and a quantitative study of the development of one of them. J. Neurosci. 6, 1037-50.

Johns, P. R. (1977). Growth of the adult goldfish eye. III. Source of the new retinal cells. J. Comp. Neurol. 176. 343-58.

Johns, P. R. (1982). Formation of photoreceptors in larval and adult goldfish. J. Neurosci. 2, 178-98.

Johns, P. R. and Easter, S. S. (1977). Growth of the adult goldfish eye. II. Increase in retinal cell number. J. Comp. Neurol. 176, 331-42.

Johns, P. R. and Fernald, R. D. (1981). Genesis of rods in teleost fish retina. Nature 293, 141-2.

Kaneko, A. (1970). Physiological and morphological identification of horizontal, bipolar and amacrine cells in goldfish retina. J. Physiol. (Lond.) 207. 623-33.

Kaneko, A. (1971). Electrical connexions between horizontal cells in the dogfish retina. J. Physiol. (Lond.) 213. 95-105.

Kaneko, A. and Stuart, A. E. (1984). Coupling between horizontal cells in the carp retina revealed by diffusion of Lucifer yellow. Neurosci. Lett. 47, 1-7.

Kock, J.-H. and Stell, W. K. (1985). Formation of new rod photoreceptor synapses onto differentiated bipolar cells in goldfish retina. Anat. Rec. 211, 69-74. 
Konigsmark, B. W. (1970). Methods for the counting of neurons. In Contemporary Research Methods in Neuroanatomy (Eds Nauta, W. J. H. and Ebbesson, S. O. E.). Pp. 315-40. New York: Springer-Verlag.

Kouyama, N. and Watanabe, K. (1986). Gap-junctional contacts of luminosity-type horizontal cells in the carp retina: A novel pathway of signal conduction from the cell body to the axon terminal. I. Comp. Neurol. 249. 404-10.

Mangel, S. C. and Dowling, J. E. (1985). Responsiveness and receptive fleld size of carp horizontal cells are reduced by prolonged darkness and dopamine. Science 229, $1107-9$.

Marc. R. E. and Liu, W.-L. S. (1984). Horizontal cell synapses onto glycine-accumulating interplexiform cells. Nature 312, 266-9.

Marc, R. E., Stell, W. K., Bok, D. and Lam, D. M. K. (1978). GABA-ergic pathways in the goldfish retina. I. Comp. Neurol. 182, 221-46.

Marshak, D. W. and Dowling, J. E. (1987). Synapses of cone horizontal cell axons in goldfish retina. J. Comp. Neurol. $256,430-43$.

Meyer, R. L. (1978). Evidence from thymidine labeling for continuing growth of retina and tectum in juvenile goldfish. Exp. Neurol. 59, 99-111.

Naka, K.-I. (1977). Functional organization of catfish retina. J. Neurophysiol. 40, 26-43.

Naka, K.-I. (1982). The cells horizontal cells talk to. Vision Res. 22. 653-60.

Negishi, K., Teranishi, T. and Kato, S. (1985). Spatial orientation of horizontal cell axon terminals in the carp retina. Brain Res. 359, 104-12.

Peng, Y. W. and Lam, D. M. K. (1989). The organization and development of axon terminals of cone horizontal cells in goldfish retina: An immunological study with monoclonal antibody AT101. Invest. Ophthalmol. Vis. Sci. 30 (Suppl.), 345.

Piccolino. M. (1986). Horizontal cells: Historical controversies and new interest. Prog. Ret. Res. 5, 147-63.

Powers, M. K., Bassi, C. J., Rone, L. A. and Raymond, P. A. (1988). Visual detection by the rod system in goldfish of different sizes. Vision Res. 28, 211-21.

Sakai, H. and Naka, K.-I. (1983). Synaptic organization involving receptor, horizontal and on- and off-center bipolar cells in the catfish retina. Vision Res. 23 , 339-52.

Sakai, H. and Naka, K.-I. (1985). Novel pathway connecting the outer and inner vertebrate retina. Nature 315 , 570-1.

Sakai, H. M. and Naka, K.I. (1986). Synaptic organization of the cone horizontal cells in the catfish retina. J. Comp. Neurol. 245, 107-15.

Sandy, J. M. and Blaxter, I. H. S. (1980). A study of retinal development in larval herring and sole. J. Mar. Biol. Assoc. U.K. 60, 59-71.
Stell, W. K. (1967). The structure and relationships of horizontal cells and photoreceptor-bipolar synaptic complexes in goldfish retina. Am. J. Anat. 121, 401-24.

Stell, W. K. (1975). Horizontal cell axons and axon terminals in goldfish retina. I. Comp. Neurol. 159, 503-20.

Stell, W. K. and Lightfoot, D. O. (1975). Color-specific interconnections of cones and horizontal cells in the retina of goldfish. J. Comp. Neurol. 159, 473-502.

Teranishi, T. (1983). Lateral spread of light-induced response at the cell body and axon terminal levels of external horizontal cells in the carp retina. Jpn. J. Physiol. 33, 417-28.

Teranishi, T., Negishi, R. and Kato, S. (1983). Dopamine modulates S-potential amplitude and dye-coupling between external horizontal cells in carp retina. Nature 301, 243-6.

Tornqvist, K., Yang, X.-L. and Dowling, J. E. (1988). Modulation of cone horizontal cell activity in the tclcost fish retina. III. Effects of prolonged darkness and dopamine on electrical coupling between horizontal cells. J. Neurosci. 8, 2279-88.

Weibel, E. R. and Bolender, R. P. (1973). Stereological techniques for electron microscopic morphometry. In Principles and Techniques of Electron Microscopy, Vol. 3 (Ed. Hayat, M. A.). Pp. 239-96. New York: Van Nostrand Reinhold.

Weiler, R. and Zettler, F. (1979). The axon-bearing horizontal cells in the teleost retina are functional as well as structural units. Vision Res. 19, 1261-8.

Wolburg, H. (1976). Influence of ouabain on the fine structure of teleost retina. Acta. Neuropath. (Berlin) 34, 255-66.

Yagi, T. and Kaneko, A. (1988). The axon terminal of goldfish retinal horizontal cells: a low membrane conductance measured in solitary preparations and its implication to the signal conduction from the soma. $J$. Neurophysiol. 59, 482-94.

Yang, K.-L., Tornqvist, K. and Dowling, J. E. (1988a). Modulation of cone horizontal cell activity in the teleost fish retina. I. Effects of prolonged darkness and background illumination on light responsiveness. I. Neurosci. 8, 2259-68.

Yang, K.-L., Tornqvist, K. and Dowling, J. E. (1988b). Modulation of cone horizontal cell activity in the teleost fish retina. II. Role of interplexiform cells and dopamine in regulating light responsiveness. J. Neurosci. 8, 2269-78.

Yazulla, S. (1985). Factors controlling the release of GABA from goldfish retinal horizontal cells. Neurosci. Res. 2 (Suppl.), S147-65.

Zucker, L. and Yazulla, S. (1984). Synaptic Organization of Dopaminergic Interplexiform Cells in the Goldfish Retina. Ph.D. dissertation. State University of New York, Stony Brook. 